Tropical Journal of Pharmaceutical Research October 2020; 19 (10): 2073-2078

ISSN: $1596-5996$ (print); 1596-9827 (electronic) (C) Pharmacotherapy Group, Faculty of Pharmacy, University of Benin, Benin City, 300001 Nigeria.

\title{
ARPC4 gene silencing inhibits T24 cell invasion and metastasis via a mechanism involving Arp2/3/cofilin-1 signaling pathway
}

\author{
Shunyi Pang ${ }^{1}$, Zeqin Yao², Chao Wang ${ }^{3}$, Guoqiang Chen ${ }^{2 *}$ \\ ${ }^{1}$ Department of Urology, Zhaoqing City Gaoyao District People's Hospital, Zhaoqing 526100, ${ }^{2}$ Department of Urology, The \\ Central Hospital of Sanya, Sanya 572000, ${ }^{3}$ Department of Urology, The First People's Hospital of Jingmen, Jingmen 448000, \\ China
}

*For correspondence: Email: frxdr1@163.com

Sent for review: 24 July 2020

Revised accepted: 28 September 2020

\begin{abstract}
Purpose: To study the influence of ARPC4 gene silencing on human urinary bladder cancer (T24) cell proliferation, invasiveness and migration, and the mechanism(s) involved.

Methods: Short interfering RNA (siRNA) ARPC4 silencing fragment was transfected into T24 cells. Transfection efficiency was measured with $q R T-P C R$. Cell proliferation, invasiveness and migratory potential were determined with CCK-8, Transwell invasion assay, and immunofluorescence assay, respectively. Protein expressions of ARPC4 and cofilin-1 were assayed using Western blotting.

Results: Short interfering RNA (siRNA) silencing of ARPC4 gene led to the downregulation of $m R N A$ and protein expressions of ARPC4 ( $t=14.898, p<0.05 ; t=7.686, p<0.05$ ). It also significantly downregulated cofilin-1 protein, while inhibiting proliferative capacity, invasiveness and pseudopodiaformation capacity of T24 cells $(t=8.042, p<0.05)$.

Conclusion: The results obtained suggest that ARPC4 gene silencing inhibits T24 cell invasion and metastasis via a mechanism involving regulation of the Arp2/3/cofilin-1 signaling route. This provides new leads for gene therapy.
\end{abstract}

Keywords: ARPC4, Bladder carcinoma, Gene silencing, Invasiveness, Cell proliferation

\begin{abstract}
This is an Open Access article that uses a funding model which does not charge readers or their institutions for access and distributed under the terms of the Creative Commons Attribution License (http://creativecommons.org/licenses/by/4.0) and the Budapest Open Access Initiative (http://www.budapestopenaccessinitiative.org/read), which permit unrestricted use, distribution, and reproduction in any medium, provided the original work is properly credited.
\end{abstract}

Tropical Journal of Pharmaceutical Research is indexed by Science Citation Index (SciSearch), Scopus, International Pharmaceutical Abstract, Chemical Abstracts, Embase, Index Copernicus, EBSCO, African Index Medicus, JournalSeek, Journal Citation Reports/Science Edition, Directory of Open Access Journals (DOAJ), African Journal Online, Bioline International, Open-J-Gate and Pharmacy Abstracts

\section{INTRODUCTION}

Bladder carcinoma refers to different kinds of cancer that affect urinary bladder tissues. It refers to malignant tumor of the mucous membrane of the bladder, and it is highly prevalent among the Chinese. Bladder cancer typically affects older adults aged 50 to 70 years [1]. About $90 \%$ of patients with bladder cancer initially show signs of hematuria (blood in the urine). As the disease progresses, bladder irritation, dysuria and upper urinary tract obstruction may occur, which seriously affect the quality of life of sufferers [2]. The condition is treatable if diagnosed early.

Since bladder cancer is likely to recur, follow-up tests are usually recommended. The treatments used for bladder cancer are cystectomy, biological therapy, radiotherapy and chemo- 
therapy. The pathogenesis of bladder cancer is complex and yet to be fully understood. It is thought to be caused by genetic and environmental factors. A highly invasive tumor, bladder cancer is characterized by rapid metastasis and recurrence, and the 5-year survival and overall prognosis are unsatisfactory [3]. At present, there is a dearth of biomarkers that can be used to effectively assess metastasis and prognosis of this disease. This has necessitated the search for novel molecules/proteins of high diagnostic and prognostic values for the disease.

Actin-related protein $2 / 3$ complex subunit 4 (ARPC4) is a subunit of Arp2/3 complex. It functions as actin-binding portion of Arp2/3 complex which controls actin polymerization, and acting in concert with NPF, regulates the generation of branched actin networks [4].

Actin-related proteins-2/3 (Arp2/3) complex is the main nucleating agent of actin assembly which is involved in the maintenance of cell morphology, cytoskeleton formation and movement [4]. It controls cell morphogenesis via the modulation of cell polarity. Studies have shown that ARPC4 expression is significantly upregulated in carcinoma of the pancreas, and that the degree of migration and invasion of the cells are significantly reduced after ARPC4 silencing [5]. The expression of ARPC4 influences the biological behavior of tumor cells [6]. The aim of this research was to study the effect of ARPC4 gene silencing on T24 cell proliferation, invasiveness and migration, and the mechanism(s) involved.

\section{EXPERIMENTAL}

\section{Materials}

Phosphate-buffered saline (PBS) was a product of Wuhan Yipu Biotechnology Co. Ltd; RPMI1640 culture medium was obtained from Shanghai Jingke Chemical Technology Co. Ltd, while BCA protein assay kits were purchased from Beijing Bio-Lab Technology Co. Ltd. Sealing liquid was obtained from Beijing YiAobo Science \& Trade Co. Ltd., while ARPC4 and cofilin-1 primary antibodies were products of Shanghai Wuhao Biotechnology Co. Ltd. Ponceau protein dye was purchased from Shanghai Yiyan Biotechnology Co. Ltd.

Micro sampler was a product of Shanghai Boguang Biotechnology Co. Ltd. Electrothermal thermostatic bath was obtained from Shanghai Xinyu Biotechnology Co. Ltd. Cryogenic $\left(-80^{\circ} \mathrm{C}\right)$ refrigerator was purchased from Shanghai Fuze
Trading Co. Ltd, while PVDF membrane was obtained from Bio-Easy Technology Co. Ltd. (Beijing). Decolorization shaker was a product of Nanjing Beideng Medical Co. Ltd. Electrophoresis tank was purchased from Shanghai Tuseng Visual Technology Co. Ltd. Low-temperature centrifuge was obtained from Sichuan Shuke Instrument Co. Ltd. Vortex oscillator was a product of Guangzhou Haohan Instrument Co. Ltd. Optical microscope was purchased from Shanghai Yiji Industrial Co. Ltd., while digital gel imaging system was obtained from Shanghai Qinxiang Scientific Instruments Co. Ltd.

\section{Cell line and culture}

Human urinary bladder cancer cell line (T24) was obtained from Shanghai Xinyu Biotech. Company Limited, and was maintained for $24 \mathrm{~h}$ at $37^{\circ} \mathrm{C}$ in RPMI-1640 containing $10 \%$ FBS and streptomycin/penicillin (1\%) in a $5 \%$ incubator until they attained $80 \%$ confluency. The medium was replaced with fresh one every two days. After 1 week of incubation, the adherent confluent cells were trypsinized with $0.25 \%$ trypsin-EDTA (2 $\mathrm{mL})$, cultured again, and passaged for later use. Cells in logarithmic growth phase were selected and used in this study.

\section{Cell transfection}

The T24 cells were seeded in 6-well plates at a density of $2 \times 10^{4}$ cells/well until they attained 80 $\%$ fusion. Then, the cells were maintained in serum-free medium with equal volume of siARPC4 (ARPC4 silenced group) or siRNA (negative control group), each at a concentration of $10 \mu \mathrm{mol} / \mathrm{L}$. Incubation was carried out at room temperature for $6 \mathrm{~h}$. Lipofectamine 2000 was dissolved in serum-free medium and incubated for proper mixing for $10 \mathrm{~min}$ at laboratory temperature. The mixture was added to cells in each group and cultured at $37^{\circ} \mathrm{C}$ in a humidified atmosphere of $5 \% \mathrm{CO}_{2}$ and $95 \%$ air for $48 \mathrm{~h}$. Normal cell culture without SiARPC4 or siRNA served as normal control group. The transfection efficiency was assessed using qRT-PCR.

\section{Quantitative reverse transcription polymerase chain reaction (qRT-PCR)}

After $48 \mathrm{~h}$ of cell transfection, total RNA was extracted from cells of each group using Trizol reagent. The RNA was reverse-transcribed to cDNA using appropriate kits. Then, Light Cycler 1536 RT-PCR detector was employed for determination of expression levels of ARPC4. Differences in cDNA levels were subjected to 
normalization with glyceraldehyde-3-phosphate dehydrogenase (GAPDH). The qRT-PCR reaction conditions were: pre-denaturation at 95 ${ }^{\circ} \mathrm{C}$ for $5 \mathrm{~min}, \mathrm{PCR}$ reaction at $95^{\circ} \mathrm{C}$ for $5 \mathrm{sec}$ and $60{ }^{\circ} \mathrm{C}$ for $30 \mathrm{sec}$, and a total of 40 cycles in a 20$\mu \mathrm{L}$ reaction solution comprising $\mathrm{dH}_{2} \mathrm{O}$, primer $(10$ $\mu \mathrm{M}), \mathrm{cDNA}$ and Premix Ex $\operatorname{Taq}^{\mathrm{TM}}$ II $(10 \mu \mathrm{L})$. Determination of relative transcription levels was done with $2^{-\Delta \Delta C t}$ method.

\section{Cell proliferation assay}

Cell proliferation was measured with CCK-8 assay kit. The cells were plated in 96-well plates [ $4 \times 10^{3}$ cells/well $(100 \mu \mathrm{L} /$ well $\left.)\right]$ and maintained for $24 \mathrm{~h}$ at $37{ }^{\circ} \mathrm{C}$ in a $5 \% \mathrm{CO}_{2}$ incubator. Then, following addition of $10 \mu \mathrm{L}$ of CCK-8, the mixture was subjected to culturing for $72 \mathrm{~h}$. The optical density of the sample was measured at $450 \mathrm{~nm}$. The assay was done thrice.

\section{Assay of cell invasiveness}

The degree of invasiveness of T24 cells was estimated with Transwell invasion procedure. The cells were placed in Transwell chamber coated at a concentration of $5 \times 10^{5}$ cells $/ \mathrm{mL}$, with substrate, and were cultured in serum-free medium. The lower chamber contained medium with $10 \%$ FBS. After $48 \mathrm{~h}$, cells that passed through the matrix gel membrane were stained with crystal violet after fixation, photographed and counted using an inverted microscope.

\section{Immunofluorescence assay}

Immunofluorescence assay was used to determine morphological changes in T24 cells. The cells were subjected to fixation in $4 \%$ paraformaldehyde on gelatin-coated coverslips and rinsed twice with PBS, each rinse for $5 \mathrm{~min}$. Following treatment with $5 \%$ BSA, overnight incubation with $1^{\circ}$ antibodies was done. After washing 3 times with PBS, FITC/TRITC-labeled secondary antibody was added, followed by incubation for $60 \mathrm{~min}$ under laboratory conditions. Thereafter, the cells were stained with DAPI for $15 \mathrm{~min}$ and washed for $5 \mathrm{~min}$. After the addition of $50 \%$ glycerol, the cells were subjected to fluorescence microscopic examination and captured in camera.

\section{Western blotting}

The cells were subjected to lysis with ice-cold RIPA buffer laced with protease inhibitor. Following centrifugation, the protein level of the supernatant was measured with BCA method in line with the kit protocol. Then, 40- $\mu \mathrm{g}$ protein fractions were subjected to SDS-PAGE, followed by electroblotting onto PVDF membrane for $2 \mathrm{~h}$. Thereafter, the membrane was blocked by incubation with $3 \%$ non-fat milk solution, after which incubation with $1^{\circ}$ antibodies for ARPC4, cofilin-1 and $\beta$-actin (all diluted 1: 800) was done for $12 \mathrm{~h}$ at $4{ }^{\circ} \mathrm{C}$. Following rinsing with TBS-T, the membrane was subjected to incubation with HRP-linked goat anti-rabbit $\operatorname{lgG} 2^{\circ}$ antibody at laboratory temperature for $90 \mathrm{~min}$. Blot development was done with X-ray film, while ImageJ Launcher software was used for Grayscale analysis. $\beta$-Actin served as standard.

\section{Statistics}

The results are presented as mean \pm SEM, and they were statistically analyzed with SPSS (version 21.0). Comparison of groups was done with Student's $t$-test. Values of $p<0.05$ indicated significant differences.

\section{RESULTS}

\section{Influence of ARPC4 gene silencing on ARPC4 mRNA expression in T24 cells}

As indicated in Figure 1, ARPC4 mRNA was significantly lower in ARPC4-silenced cells, relative to negative control. In contrast, ARPC4 mRNA expressions in negative and normal control groups were comparable.

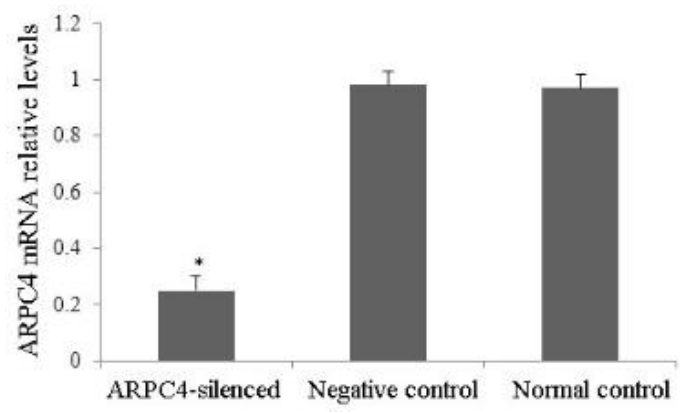

Figure 1: Influence of ARPC4 silencing on ARPC4 mRNA expression in T24 cells. ${ }^{*} p<0.05$, vs negative control

\section{Influence of ARPC4 gene silencing on T24 cell proliferation}

As shown in Table 1, ARPC4 gene silencing markedly suppressed the proliferative potential of T24 cells.

\section{Effect of ARPC4 silencing on T24 cell invasiveness}

Human urinary bladder cancer (T24) cells in ARPC4-silenced group were significantly less 
invasive than cells in the negative control group $(p<0.05$; Table 2).

Table 1: Effect of ARPC4 gene silencing on T24 cell proliferation (mean $\pm S D, n=6$ )

\begin{tabular}{llll}
\hline \multirow{2}{*}{ Group } & \multicolumn{3}{c}{ Time (h) } \\
\cline { 2 - 4 } & $\mathbf{4 8}$ & $\mathbf{7 2}$ & $\mathbf{9 6}$ \\
\hline ARPC4- & $0.61 \pm$ & $0.80 \pm$ & $0.91 \pm$ \\
silenced & $0.05^{\star}$ & $0.09^{*}$ & $0.08^{*}$ \\
Negative & $0.81 \pm$ & $1.13 \pm$ & $1.52 \pm$ \\
control & 0.04 & 0.07 & 0.08 \\
Normal & $0.80 \pm$ & $1.20 \pm$ & $1.61 \pm$ \\
control & 0.06 & 0.07 & 0.07 \\
\hline${ }^{*} P<0.05$, vs & $-v e$ control at same period
\end{tabular}

Table 2: Effect of ARPC4 silencing on T24 cell invasiveness (mean $\pm S D, n=6$ )

\begin{tabular}{lc}
\hline Group & $\begin{array}{c}\text { No. of transmembrane } \\
\text { cells }\end{array}$ \\
\hline $\begin{array}{l}\text { ARPC4- } \\
\text { silenced }\end{array}$ & $32.40 \pm 2.48^{*}$ \\
$\begin{array}{l}\text { Negative } \\
\text { control }\end{array}$ & $59.05 \pm 1.86$ \\
Normal & $62.02 \pm 1.77$ \\
control & \\
\hline${ }^{*} P<0.05$, vs -ve control at same period
\end{tabular}

Effect of ARPC4 gene silencing on T24 cell morphology

The results of immunofluorescence assay showed that ARPC4 gene silencing significantly inhibited pseudopodia formation in T24 cells $(p<$ 0.05; Figure 2).

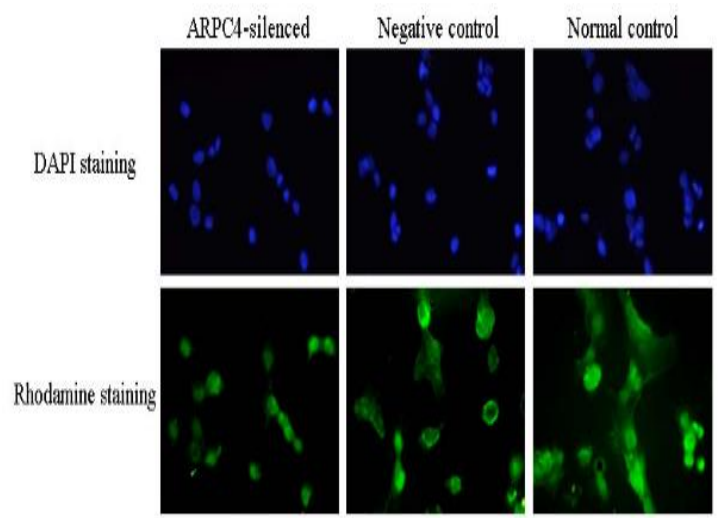

Figure 2: Influence of ARPC4 gene silencing on T24 cell morphology

Effect of ARPC4 silencing on protein expressions of ARPC4 and cofilin-1

The silencing of ARPC4 gene led to the downregulation of ARPC4 and cofilin-1 protein expressions $(p<0.05$; Table 3 , Figure 3$)$.
Table 3: Effect of ARPC4 silencing on ARPC4 and cofilin-1 protein expressions

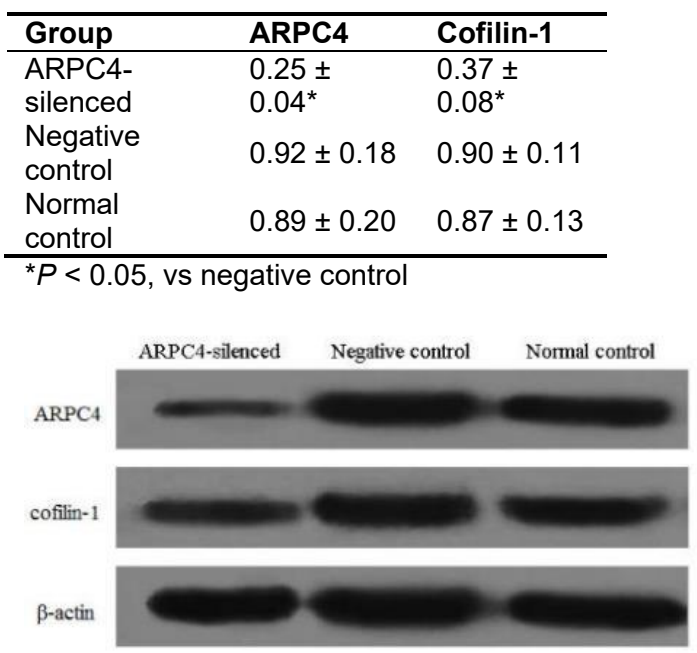

Figure 3: Effect of ARPC4 silencing on ARPC4 and cofilin-1 protein expressions

\section{DISCUSSION}

Bladder cancer, a frequently-occurring malignancy in the urinary tissues, is pathologically classified into two types: muscle invasive and non-muscle invasive bladder cancer. Muscle-invasive bladder cancer is highly metastatic, with a 5-year survival of about $50 \%$ [7]. Studies on the mechanism of bladder cancer cell infiltration and metastasis are centered on novel therapeutic targets that can effectively improve prognosis and survival of patients.

The pathogenesis of this disease is complex and multifactorial [8]. Abnormal protein expressions are thought to contribute to the disease onset. Gene mutations affect the use of nutrients and increase the risk of cancer. Increased expression of oncogenes and downregulation or inactivation of tumor suppressor genes are key factors in tumor formation. An important characteristic of tumor cells is their ability to proliferate without restriction, thereby eventually invading other cells or tissues.

The ARPC4, a subunit of Arp2/3 complex, participates in the aggregation and depolymerization of actin. It influences cell motility, and also promotes the synthesis of microfilaments, formation of cytoskeleton and invasive pseudopodia in cancer cells [10]. The cytoskeleton is a complex and dynamic network of interlinking cytoplasmic protein filaments. It plays important roles in the maintenance of cell morphology, motility and other biological behaviors of tumor cells, such as invasion and 
metastasis. Therefore, structural changes in the cytoskeleton contribute significantly to the initiation and progression of tumors $[11,12]$.

Studies have shown that ARPC4 protein expression is significantly upregulated in gastric cancer cells, and it is linked to tumor volume, degree of infiltration, invasion and metastasis $[13,14]$. Similarly, significantly high expression of ARPC4 is found in the serum of colorectal cancer (CRC) patients, and is correlated with lymph node and distant metastasis. Results from animal studies have demonstrated that the downregulation of ARPC4 protein significantly inhibited the invasion and metastasis potential of CRC cells [15-18].

In the present study, siRNA silencing of ARPC4 gene led to the downregulation of mRNA and protein expressions of ARPC4. It also markedly suppressed the proliferative capacity and invasiveness of T24 cells. Results from immunofluorescence assay revealed that the formation of pseudopodia in T24 cells was significantly affected by ARPC4 silencing. These results indicate that ARPC4 silencing may inhibit T24 cell proliferation and invasion, and block the formation of pseudopodia via the regulation of Arp2/3-cofilin-1 signaling pathway.

\section{CONCLUSION}

The results obtained in this study suggest that ARPC4 gene silencing inhibits T24 cell invasion and metastasis via a mechanism involving the Arp2/3-cofilin-1 signaling pathway. These findings can provide new leads for gene therapy.

\section{DECLARATIONS}

\section{Conflict of interest}

No conflict of interest is associated with this work.

\section{Contribution of authors}

This study was done by the authors named in this article, and the authors accept all liabilities resulting from claims which relate to this article and its contents. The study was conceived and designed by Guoqiang Chen. Shunyi Pang, Zeqin Yao, Chao Wang and Guoqiang Chen collected and analyzed the data, while Shunyi Pang and Zeqin Yao wrote the manuscript. All authors read and approved the manuscript for publication.

Shunyi Pang and Zeqin Yao contributed equally to this work and should be considered as co-first authors.

\section{Open Access}

This is an Open Access article that uses a funding model which does not charge readers or their institutions for access and distributed under the terms of the Creative Commons Attribution License (http://creativecommons.org/licenses/by/ 4.0) and the Budapest Open Access Initiative (http://www.budapestopenaccessinitiative.org/rea d), which permit unrestricted use, distribution, and reproduction in any medium, provided the original work is properly credited.

\section{REFERENCES}

1. Minami $K$, Taniguchi $K$, Sugito $N$, Kuranaga $Y$, Inamoto T, Takahara K, Takai T, Yoshikawa Y, Kiyama S, Akao $Y$, et al. MiR-145 negatively regulates Warburg effect by silencing KLF4 and PTBP1 in bladder cancer cells. Oncotarget 2017; 8(20): 33064-33077.

2. Chou R, Selph S, Buckley DI, Fu R, Griffin JC, Grusing S, Gore JL. Intravesical Therapy for the Treatment of Nonmuscle Invasive Bladder Cancer: A Systematic Review and Meta-Analysis. J Urol 2017; 197(5): 1189-1195.

3. Pichler R, Tulchiner G, Fritz J, Schaefer G, Horninger W, Heidegger I. Urinary UBC Rapid and NMP22 Test for Bladder Cancer Surveillance in Comparison to Urinary Cytology: Results from a Prospective Single-Center Study. Int J Med Sci 2017; 14(9): 811-819.

4. Qin G, Dang $M$, Gao $H$, Wang $H$, Luo $F$, Chen $R$. Deciphering the protein-protein interaction network regulating hepatocellular carcinoma metastasis. Biochim Biophys Acta Proteins Proteom 2017; 1865(9): 11141122.

5. Nicolas M, Alexis G. The Arp2/3 Regulatory System and Its Deregulation in Cancer. Physiol Rev 2018; 98(1): 215-226.

6. Zhao M, Spiess $M$, Johansson $H J$, Olofsson $H, H u J$, Lehtiö J, Strömblad S. Identification of the PAK4 interactome reveals PAK4 phosphorylation of $N$-WASP and promotion of Arp2/3-dependent actin polymerization. Oncotarget 2017; 8(44): 77061-77074.

7. Shang $A$, Yang $M$, Shen $F$, Wang J, Wei J, Wang $W$, Lu W, Wang C, Wang C. MiR-1-3p Suppresses the Proliferation, Invasion and Migration of Bladder Cancer Cells by Up-Regulating SFRP1 Expression. Cell Physiol Biochem 2017; 41(3): 1179-1188.

8. Zhuang J, Shen L, Yang L, Huang X, Lu Q, Cui Y, Zheng $X$, Zhao $X$, Zhang $D$, Huang $R$, et al. TGF $\beta 1$ Promotes Gemcitabine Resistance through Regulating the LncRNA-LET/NF90/miR-145 Signaling Axis in Bladder Cancer. Theranostics 2017; 7(12): 3053-3067.

9. Linscott JA, Smith AB, Sammon JD. Re: Woonyoung Choi, Andrea Ochoa, David J. McConkey, et al. Genetic Alterations in the Molecular Subtypes of Bladder

Trop J Pharm Res, October 2020; 19(10): 2077 
Cancer: Illustration in the Cancer Genome Atlas Dataset. Eur Urol 2017; 72(3): 354-359.

10. Ikeno T, Konishi Y. Arp2/3 Is Required for Axonal Arbor Terminal Retraction in Cerebellar Granule Neurons. Neurochem J 2020; 14(1): 32-36.

11. Schrank BR, Aparicio $T, L i Y$, Chang $W$, Chait BT, Gundersen GG, Gottesman ME, Gautier J. Nuclear ARP2/3 drives DNA break clustering for homologydirected repair. Nature 2018; 559(7712): 61-66.

12. Lam JGT, Vadia S, Pathak-Sharma S, McLaughlin E, Zhang $X$, Swanson J, Seveau S. Host cell perforation by listeriolysin $O$ (LLO) activates a $\mathrm{Ca}^{2+}$-dependent cPKC/Rac1/Arp2/3 signaling pathway that promotes $L$. monocytogenes internalization independently of membrane resealing. Mol Biol Cell 2017; 29(3): 270284.

13. Trylinski M, Schweisguth F. Activation of Arp2/3 by WASp Is Essential for the Endocytosis of Delta Only during Cytokinesis in Drosophila. Cell Rep 2019; 28(1): 1-10.
14. Billault-Chaumartin I, Martin S. Capping Protein Insulates Arp2/3-Assembled Actin Patches from Formins. Current Biol 2019; 29(19): 3165-3176.

15. Georgopoulou MP, Tosios KI, Goutas N, Kouloukoussa M. Arp2/3 Complex Is Expressed in Oral Squamous Cell Carcinoma: An Immunohistochemical Study of 88 Cases. Open J Stomatol 2019; 9(3): 29-38.

16. Li D, Lixia Y, Fengsui L, Haitao Z, Xinwei C. Farrerol ameliorates diabetic hepatopathy in rat model of type 2 diabetes mellitus via modulation of oxidative inflammatory stress. Trop J Pharm Res 2020; 19(1): 7176.

17. Li SP, Hu SM. Cinnamic hydroxamic acid inhibits the proliferation of gastric cancer cells via upregulation of miR 145 expression and down-regulation of P13K/Akt signaling pathway. Trop J Pharm Res 2020; 19(5): 957963.

18. $X u N, Q u G Y, W u Y P$, Lin YZ, Chen DN, Li XD, Chen SH, Huang JB, Zheng QS, Xue $X Y$, et al. ARPC4 promotes bladder cancer cell invasion and is associated with lymph node metastasis. J Cell Biochem 2020; 121(1): 231-243. 